\title{
SYNTHESIS OF ACETYL AND BENZOYL ESTERS OF XANTHORRHIZOL AND ITS OXIDATION PRODUCTS AND EVALUATION OF THEIR INHIBITORY ACTIVITY AGAINST NITRIC OXIDE PRODUCTION
}

\author{
MAYA DAMAYANTI RAHAYU ${ }^{1}$, SUSI KUSUMANINGRUM ${ }^{1}$, HAYUN HAYUN ${ }^{2 *}$ \\ ${ }^{1}$ Center of Pharmaceutical and Medical Technology, Agency for the Assessment and Application of Technology (BPPT), Jakarta, Indonesia. \\ ${ }^{2}$ Laboratory of Pharmaceutical and Medicinal Chemistry, Faculty of Pharmacy, Universitas Indonesia, Depok, West Java, Indonesia. \\ Email: hayun@farmasi.ui.ac.id
}

Received: 28 October 2019, Revised and Accepted: 10 January 2020

\section{ABSTRACT}

Objective: Xanthorrhizol is known to have anti-inflammatory activity. However, new xanthorrhizol derivatives with improved anti-inflammatory activity and reduced toxicity are needed.

Methods: In this study, the derivatives of xanthorrhizol were synthesized and spectroscopically characterized, and their inhibitory activities against nitric oxide (NO) production were evaluated in RAW 264.7 macrophage cells.

Results: The first stage of synthesis produced compounds $\mathbf{2 a}$ and $\mathbf{2 b}$ in $58.49 \%$ and $63.26 \%$ yields, respectively. Compounds $\mathbf{2 a}$ and $\mathbf{2 b}$ were oxidized using potassium permanganate, giving compounds $\mathbf{3 a}$ and $\mathbf{3 b}$ in yields of $51.92 \%$ and $43.78 \%$, respectively. Compounds $1, \mathbf{2 a}$, 3a, and $\mathbf{3 b}$ along with diclofenac sodium (the positive control) exhibited IC50 values for NO production of 31.82, 73.85, 354.05, 97.19, and 78.43 $\mu \mathrm{M}$, respectively. In contrast, compound $\mathbf{2 b}$ did not show any inhibitory activity. Based on cytotoxicity assay, compounds 1, 2a, 2b, 3a, 3ba and diclofenac sodium had LD50 values of $30.97,65.15,31.15,117.86,53.40$, and $51.67 \mu \mathrm{M}$, respectively. The NO inhibitory activities of compounds $\mathbf{2 a}$, $\mathbf{3 a}$, and $\mathbf{3 b}$ were lower than that of xanthorrhizol (compound 1). However, cytotoxicity tests showed that compounds $\mathbf{2 a} \mathbf{a}$, $\mathbf{3 a}$, and $\mathbf{3} \mathbf{b}$ had reduced toxicities compared to xanthorrhizol.

Conclusion: The modification of xanthorrhizol through esterification and oxidation produced derivative compounds with weaker anti-inflammatory activity but reduced cytotoxicity.

Keywords: Xanthorrhizol, Oxidation, Potassium permanganate, Nitric oxide, RAW 264.7 cells.

(c) 2020 The Authors. Published by Innovare Academic Sciences Pvt Ltd. This is an open access article under the CC BY license (http://creativecommons. org/licenses/by/4. 0/) DOI: http://dx.doi.org/10.22159/ijap.2020.v12s1.FF030

\section{INTRODUCTION}

Inflammation is a protective immune response designed to protect against pathogenic infections and tissue injuries [1]. To reduce inflammation, nonsteroidal anti-inflammatory drugs (NSAIDs) are commonly prescribed. NSAIDs work by inhibiting cyclooxygenase (COX) enzymes, which catalyze the conversion of arachidonic acid into the inflammatory mediators prostaglandin and thromboxane $[2,3]$. However, NSAIDs, which inhibit the COX-1 enzyme activity, have toxic effects on the gastrointestinal tract, especially the stomach, and the inhibition of COX-2 enzyme increases cardiovascular risk [4]. Therefore, novel anti-inflammatory drugs with different targets are desired.

When developing anti-inflammatory drugs, an alternative to COX enzyme inhibition is the hindrance of nitric oxide (NO) production. In addition to COX inhibition, some NSAIDs also inhibit NO production by restraining inducible NO synthase (iNOS) expression. For example, diclofenac sodium, an NSAID, inhibits iNOS gene expression at the transcription level by suppressing nuclear factor kappa B activity. The inhibition of iNOS gene expression ultimately results in a reduction in NO production [5] and NOS inhibitors found to be effective in treating experimentally induced arthritis [6].

Xanthorrhizol, a major component of Curcuma xanthorrhiza, is a known anti-inflammatory agent [7-10]. The inhibition of NO production by xanthorrhizol in RAW 264.7 cells stimulated by lipopolysaccharide (LPS) was previously investigated [11]. Xanthorrhizol has been found to restrict iNOS and COX expression in the skin of mice with acute inflammation under stimulation by 12-0-tetradecanoylphorbol-13acetate [7]. Xanthorrhizol derivatization has been carried out through modifications to the xanthorrhizol structure, including the conversion of hydroxyl groups into ester groups $[12,13]$ and the addition of epoxides and diols into the unsaturated chain using a weak oxidizing agent [12]. However, a new process to obtain novel derivatives of xanthorrhizol is needed to obtain compounds with enhanced anti-inflammatory ability and lower toxicity. Potassium permanganate $\left(\mathrm{KMnO}_{4}\right)$ is an important strong oxidizing agent which is very useful for oxidizing carbon-carbon double bonds in organic compounds [14]. We have recently reported the oxidation of 1-0-acetyl-xanthorrhizol using permanganate to obtain an $\alpha$-hydroxyl ketone of the compound, but the synthesis of other derivatives and evaluation of their biological activities have not been reported [15].

Herein, we report the synthesis of other derivatives of xanthorrhizol and the evaluation of anti-inflammatory activities of all obtained derivatives by testing their inhibition of NO production in vitro using RAW 264.7 macrophage cells stimulated by LPS.

\section{EXPERIMENTAL METHODS}

Materials and instruments

All solvents, chemicals, and reagents were commercially purchased. Xanthorrhizol was supplied by Java Plant (Karanganyar, Indonesia). The purity of xanthorrhizol was evaluated by thin-layer chromatography (TLC) on silica gel 60 F254 plates (Merck). Fourier transform infrared (FTIR) spectra were recorded using an FTIR spectrophotometer (Nicolet iS10, Thermo Fisher Scientific, Waltham, MA, USA). Nuclear magnetic resonance (NMR) spectra were collected using an NMR spectrometer (Agilent, Santa Clara, CA, USA) at $500 \mathrm{MHz}$ for protons and $125 \mathrm{MHz}$ for carbon atoms with deuterated chloroform $\left(\mathrm{CDCl}_{3}\right)$ as 
solvent and tetramethylsilane as an internal standard. High-resolution mass spectrometry (HR-MS) was carried out on an LCT Premier XETOF mass spectrometer (Waters Corp., Milford, MA, USA) in positive electrospray ionization (ESI) mode.

\section{Chemistry}

Synthesis of 2-methyl-5-(6-methylhept-5-en-2-yl)phenyl acetate (2a)

Compound 2a was prepared using the previously reported method with slight modification $[16,17]$. The salt used in this study was dried at $90^{\circ} \mathrm{C}$ before the synthesis. In a boiling flask, xanthorrhizol $(5 \mathrm{mmol}$, $1091.65 \mathrm{mg}$ ) was dissolved in $30 \mathrm{~mL}$ ethyl acetate. $\mathrm{NaHCO}_{3}(50 \mathrm{mmol}$, $4200.35 \mathrm{mg}$ ) and acetate anhydride (100 mmol, $10.209 \mathrm{mg})$ were then added and stirred at room temperature for $24 \mathrm{~h}$. The reaction was monitored by TLC until the reaction was complete. The formed precipitate was filtered, and the filtrate was concentrated. The obtained residue was then extracted using dichloromethane $(15 \mathrm{~mL})$ and water $(5 \mathrm{~mL})$. The organic phase was collected and dried by adding $\mathrm{Na}_{2} \mathrm{SO}_{4}$. Subsequently, the product was concentrated by evaporating the solvent using a rotary evaporator. Finally, the product was purified by column chromatography using a mixture of hexane and ethyl acetate $(9: 1 \mathrm{v} / \mathrm{v})$ to obtain pure $\mathbf{2 a}$.

Synthesis of 2-methyl-5-(6-methylhept-5-en-2-yl)phenyl benzoate (2b) Compound $\mathbf{2 b}$ was synthesized using a reported method with slight modification [16,17]. Xanthorrhizol $(1.084 \mathrm{~g}, 5 \mathrm{mmol})$ was dissolved in $10 \mathrm{~mL}$ of $5 \% \mathrm{NaOH}$ at $0^{\circ} \mathrm{C}-5^{\circ} \mathrm{C}$. Benzoyl chloride $(0.581 \mathrm{~mL}, 5 \mathrm{mmol})$ was added to the mixture followed by stirring until no benzoyl chloride fumes were present. The product was separated using dichloromethane and concentrated. The product was then purified by column chromatography using a mixture of hexane and ethyl acetate $(9: 1, v / v)$ to obtain pure $\mathbf{2 b}$.

Synthesis of 5-(6-hydroxy-6-methyl-5-oxoheptan-2-yl)-2-methylphenyl acetate (3a)

Compound 3a was prepared according to the procedure reported in our previous publication [15].

Synthesis of 5-(6-hydroxy-6-methyl-5-oxoheptan-2-yl)-2-methylphenyl benzoate $(3 \boldsymbol{b})$

Compound $\mathbf{3 b}$ was synthesized using a previously reported method[18]. Compound $2 \mathbf{b}$ (2.206 mmol), glacial acetic acid (4.941 mL), acetone $(11 \mathrm{~mL})$, and distilled water $(3.81 \mathrm{~mL})$ were added to a three-neck boiling flask. After conditioning the mixture at $0^{\circ} \mathrm{C}-5^{\circ} \mathrm{C}, \mathrm{KMnO}_{4}$ crystals $(2.42 \mathrm{mmol}, 386.62 \mathrm{mg}$ ) were added slowly for $6 \mathrm{~h}$ followed by stirring for an additional $1 \mathrm{~h}$. The reaction was monitored until completion using TLC. Subsequently, the solution was transferred into $10.83 \mathrm{~mL}$ of distilled water. $\mathrm{H}_{2} \mathrm{O}_{2}$ was then added until a clear solution formed. The obtained product was extracted using dichloromethane and then purified by column chromatography using a mixture of hexane, ethyl acetate, and methanol $(8: 2: 1 \mathrm{v} / \mathrm{v} / \mathrm{v})$.

\section{Anti-inflammatory activity}

\section{Cell culture}

Murine macrophage cells (RAW 264.7, BPPT collection) were cultured at $37^{\circ} \mathrm{C}$ in Roswell Park Memorial Institute medium containing $10 \%$ fetal bovine serum (FBS) in a humidified incubator with $5 \% \mathrm{CO}_{2}$

\section{Measurement of NO}

NO was determined by calculating the quantity of nitrite from sodium nitrite in the cell culture medium using Griess reagent as reported previously $[11,19]$. NO inhibition was analyzed in RAW 264.7 cells that had been stimulated using LPS. Seeded cells were placed in 96-well culture plates at a density of $1 \times 10^{5}$ cells $/$ well and incubated at $37^{\circ} \mathrm{C}$ in an incubator containing $5 \% \mathrm{CO}_{2}$ for $24 \mathrm{~h}$. After incubation, the medium was discarded and replaced with various concentrations of each sample in serum ( $2 \% \mathrm{FBS})$ for $2 \mathrm{~h}$. LPS was added to each well to achieve a final LPS concentration of $1 \mathrm{ppm}$. The cells were then reincubated for $24 \mathrm{~h}$.
Cell culture supernatant ( $75 \mu \mathrm{L}$ ) was mixed with Griess reagent (75 $\mu \mathrm{L}$ ) in a new 96-well plate in the dark for $20 \mathrm{~min}$. Finally, the absorption was measured spectrophotometrically at $540 \mathrm{~nm}$. The NO concentration $(A)$ was calculated using a sodium nitrite standard curve, and the inhibition of NO was then calculated as follows:

$$
\% \text { NOinhibition }=\frac{A-B}{B} \times 100
$$

Where, B is the NO concentration after treatment.

\section{Cytotoxicity assay against RAW 264.7 macrophage cells}

Cytotoxicity of the synthesized compounds on RAW 264.7 macrophages was determined using 3-(4,5-dimethylthiazol-2-yl)-2,5diphenyltetrazolium bromide (MTT) method [11]. RAW 264.7 cells were added to 96-well culture plates at a density of $1 \times 10^{4}$ cells/well and left to attach for $24 \mathrm{~h}$ in an incubator at $37^{\circ} \mathrm{C}$ with $5 \% \mathrm{CO}_{2}$. After cell growth, the medium was removed and replaced with various concentrations of each sample in serum (2\% FBS) for $24 \mathrm{~h}$. After incubation, the culture medium was discarded, and (MTT: $0.5 \mathrm{mg} / \mathrm{mL}$, $100 \mu \mathrm{L}$ ) solution was added to each cell. The cells were then reincubated at $37^{\circ} \mathrm{C}$ in an incubator containing $5 \% \mathrm{CO}_{2}$ for $4 \mathrm{~h}$. After removing the culture supernatants, $200 \mu \mathrm{L}$ dimethyl sulfoxide was added followed by agitation for $10 \mathrm{~min}$ in the dark. The absorption at $570 \mathrm{~nm}(T)$ was measured using a spectrophotometer, and cell viability was calculated as follows:

$$
\text { Cellviability }(\%)=100-\left(\frac{\mathrm{C}-\mathrm{T}}{\mathrm{C}} \times 100 \%\right)
$$

Where, $\mathrm{C}$ is the absorption of the control. The $\mathrm{IC}_{50}$ value was calculated by plotting cell viability against $\log$ concentration $(\log \mathrm{C})$ of the tested compounds using SPSS software.

\section{RESULTS AND DISCUSSION}

\section{Chemistry}

The synthetic method used to obtain xanthorrhizol derivatives is shown in Fig. 1. The hydroxyl groups of xanthorrhizol were first esterified either using acetic anhydride with $\mathrm{NaHCO}_{3}$ as a catalyst to give $\mathbf{2 a}$ or using benzoyl chloride with $\mathrm{NaOH}$ as a catalyst to give $\mathbf{2} \mathbf{b}$. Second, the oxidation of $\mathbf{2 a}$ and $\mathbf{2} \mathbf{b}$ using a strong oxidizing agent $\left(\mathrm{KMnO}_{4}\right)$ in the presence of weak acid (acetic acid) at $0^{\circ} \mathrm{C}-5^{\circ} \mathrm{C}$ and water/acetone as solvent gave compounds $\mathbf{3 a}$ and $\mathbf{3 b}$.

\section{Spectroscopy data of the synthesized compounds}

2-Methyl-5-(6-methylhept-5-en-2-yl)phenyl acetate (2a)

Compound 2a was obtained as a yellow oil in $58.49 \%$ yield: FTIR (KBr) $\mathrm{cm}^{-1}, 2964.21$ and 2926, 13 (C-H aliphatic), 1768.06 (C=0, ester), 1214.16 (C-0, ester). ${ }^{1} \mathrm{H}-\mathrm{NMR}$ (500 MHz, $\left.\mathrm{CDCl}_{3}\right), \delta(\mathrm{ppm}): 7.14(1 \mathrm{H}, \mathrm{d}$, $\mathrm{J}=7.8, \mathrm{Ar}-\mathrm{H}), 6.97(1 \mathrm{H}, \mathrm{d}, \mathrm{J}=6, \mathrm{Ar}-\mathrm{H}), 6.81(1 \mathrm{H}, \mathrm{s}, \mathrm{Ar}-\mathrm{H}), 5.07(1 \mathrm{H}, \mathrm{m}$, $\left.\mathrm{CH}_{2}-\mathrm{CH}=\mathrm{C}\right), 2.67,(1 \mathrm{H}, \mathrm{m}, \mathrm{CH}-\mathrm{Ar}), 2.31\left(3 \mathrm{H}, \mathrm{s}, \mathrm{CH}_{3}\right.$ acetate $), 2.14(3 \mathrm{H}$, s, $\left.\mathrm{CH}_{3}-\mathrm{Ar}\right), 1.89\left(2 \mathrm{H}, \mathrm{m}, \mathrm{CH}_{2}-\mathrm{CH}_{2}-\mathrm{CH}\right), 1,66\left(3 \mathrm{H}, \mathrm{s}, \mathrm{CH}_{3}-\mathrm{C}, 1.58(2 \mathrm{H}\right.$, $\left.\mathrm{m}, \mathrm{CH}-\mathrm{CH}_{2}-\mathrm{CH}_{2}\right), 1.52\left(3 \mathrm{H}, \mathrm{s}, \mathrm{CH}_{3}-\mathrm{C}\right), 1,22\left(3 \mathrm{H}, \mathrm{d}, \mathrm{J}=1.39, \mathrm{CH}_{3}-\mathrm{CH}\right)$, ${ }^{13} \mathrm{C}$-NMR (500 MHz, CDCl3) $\delta / \mathrm{ppm}: 169.35$ (C=O acetate), 149.42 (C-0 acetate), 147.07 (CAr), $131.65\left(\mathrm{CH}=\mathrm{C}-\left(\mathrm{CH}_{3}\right)_{2}\right.$ aliphatic), 130.9 (CAr), 127.31 (CAr), 124.85 (CAr), $124.51\left(\mathrm{CH}_{2}-\mathrm{CH}=\mathrm{C}\right), 120.47$ (CAr), 38.99 (CH-Ar), $38.48\left(\mathrm{CH}-\mathrm{CH}_{2}-\mathrm{CH}_{2}\right), 26.21\left(\mathrm{CH}_{2}-\mathrm{CH}_{2}-\mathrm{CH}\right), 25.85\left(\mathrm{CH}_{3}-\mathrm{C}\right)$, $22.30\left(\mathrm{CH}_{3}-\mathrm{CH}\right), 20.97\left(\mathrm{CH}_{3}\right.$-acetate), $17.81\left(\mathrm{CH}_{3}-\mathrm{C}\right), 15.93\left(\mathrm{CH}_{3}-\mathrm{Ar}\right)$. HR ESI-MS m/z: $283.1680[\mathrm{M}+\mathrm{Na}]^{+}$calculated for $\mathrm{C}_{17} \mathrm{H}_{24} \mathrm{O}_{2} \mathrm{Na}$ : 283.1674.

\section{2-Methyl-5-(6-methylhept-5-en-2-yl)phenyl benzoate (2b)}

Compound $\mathbf{2 b}$ was obtained as a yellow oil in $63.2 \%$ yield: FTIR $(\mathrm{KBr})$ $\mathrm{cm}^{-1}, 2962.75$ and 2924.22 (C-H aliphatic), 1737.90 (C=O ester), 1263.59 (C-0 ester). ${ }^{1} \mathrm{H}-\mathrm{NMR}\left(500 \mathrm{MHz}, \mathrm{CDCl}_{3}\right), \delta(\mathrm{ppm}): 8.23(1 \mathrm{H}, \mathrm{d}$, $\mathrm{J}=8.55, \mathrm{Ar}-\mathrm{H}), 7.52(1 \mathrm{H}, \mathrm{m}, \mathrm{Ar}-\mathrm{H}), 7.64(1 \mathrm{H}, \mathrm{m}, \mathrm{Ar}-\mathrm{H}), 7.18(1 \mathrm{H}, \mathrm{d}, \mathrm{J}=7.8$, $\mathrm{Ar}-\mathrm{H}), 7.02(1 \mathrm{H}, \mathrm{d}, \mathrm{J}=7.75, \mathrm{Ar}-\mathrm{H}), 6.96(1 \mathrm{H}, \mathrm{s}, \mathrm{Ar}-\mathrm{H}), 5.09\left(1 \mathrm{H}, \mathrm{m}, \mathrm{CH}_{2}-\right.$ $\mathrm{CH}=\mathrm{C}), 2.7(1 \mathrm{H}, \mathrm{m}, \mathrm{CH}-\mathrm{Ar}), 2.19\left(3 \mathrm{H}, \mathrm{s}, \mathrm{CH}_{3}-\mathrm{Ar}\right), 1.92\left(2 \mathrm{H}, \mathrm{m}, \mathrm{CH}_{2}-\mathrm{CH}_{2}-\right.$ $\mathrm{CH}), 1.67\left(3 \mathrm{H}, \mathrm{s}, \mathrm{CH}_{3}-\mathrm{C}\right), 1.6\left(2 \mathrm{H}, \mathrm{m}, \mathrm{CH}-\mathrm{CH}_{2}-\mathrm{CH}_{2}\right), 1.54\left(3 \mathrm{H}, \mathrm{s}, \mathrm{CH}_{3}-\mathrm{C}\right)$, 


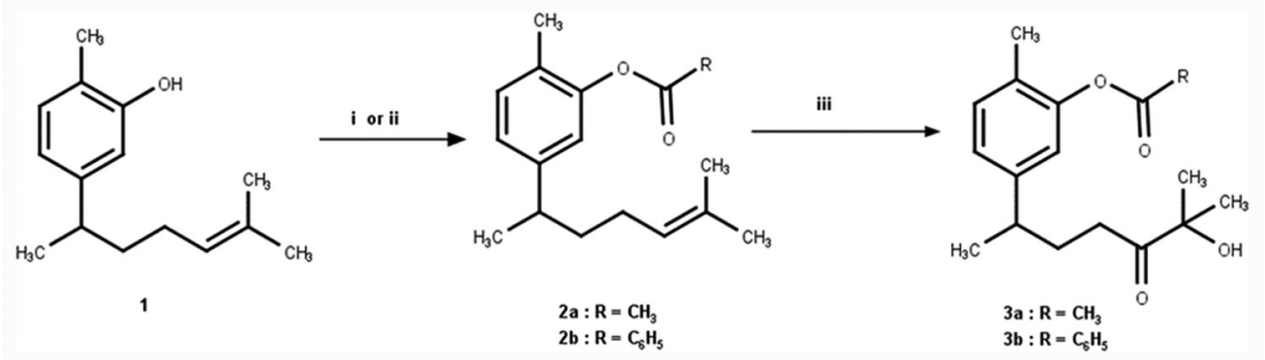

Fig. 1: Structures and synthetic routes of xanthorrhizol derivatives. Reaction conditions: (i) Acetic anhydride $\mathrm{NaHCO}_{3}$ ethyl acetate, rt; (ii) benzoyl chloride, $\mathrm{NaOH}$, cold $\left(0^{\circ} \mathrm{C}-5^{\circ} \mathrm{C}\right)$; and (iii) $\mathrm{KMnO}_{4}$, acetic acid, acetone, water, $0^{\circ} \mathrm{C}-5^{\circ} \mathrm{C}$

Table 1: Cytotoxicities and inhibitory activities for NO production of different compounds in RAW 264.7 cells induced by LPS

\begin{tabular}{lll}
\hline Compound & $\mathbf{I C}_{\mathbf{5 0}}(\boldsymbol{\mu M})^{\mathbf{1}}$ & $\mathbf{L D}_{50}(\boldsymbol{\mu M})^{\mathbf{2}}$ \\
\hline $\mathbf{1}$ & 31.82 & 30.97 \\
$\mathbf{2 a}$ & 73.85 & 65.15 \\
$\mathbf{2 b}$ & - & 31.15 \\
$\mathbf{3 a}$ & 354.05 & 117.86 \\
$\mathbf{3 b}$ & 97.19 & 53.40 \\
Diclofenac sodium & 78.43 & 51.67 \\
\hline
\end{tabular}

${ }^{1}$ NO production inhibition, ${ }^{2}$ Cytotoxicity. NO: Nitric oxide,

LPS: Lipopolysaccharide

$1.25\left(3 \mathrm{H}, \mathrm{d}, \mathrm{J}=6.9 \mathrm{CH}_{3}-\mathrm{CH}\right),{ }^{13} \mathrm{C}-\mathrm{NMR}\left(500 \mathrm{MHz}, \mathrm{CDCl}_{3}\right) \delta(\mathrm{ppm}): 164.97$ $(\mathrm{C}=0), 149.61(\mathrm{C}-0), 147.13(\mathrm{CAr}), 133.61(\mathrm{CAr}), 131.65\left(\mathrm{CH}=\mathrm{C}-\left(\mathrm{CH}_{3}\right)_{2}\right.$, 131.02 (CAr), 130.28 (CAr), 129.8 (CAr), 128.71 (CAr), 127.53 (CAr), 124.88 (CAr), $124.54\left(\mathrm{CH}_{2}-\mathrm{CH}=\mathrm{C}\right), 120.61(\mathrm{CAr}), 39.05$ (CH-Ar), 38.51 $\left(\mathrm{CH}-\mathrm{CH}_{2}-\mathrm{CH}_{2}\right), 26.24\left(\mathrm{CH}_{2}-\mathrm{CH}-\mathrm{CH}\right), 25.86\left(\mathrm{CH}_{3}-\mathrm{C}\right), 22.35\left(\mathrm{CH}_{3}-\mathrm{CH}\right)$, $17.83\left(\mathrm{CH}_{3}-\mathrm{C}\right), 16.04\left(\mathrm{CH}_{3}-\mathrm{Ar}\right)$, HR ESI-MS m/z: $345.1827[\mathrm{M}+\mathrm{Na}]^{+}$ calculated for $\mathrm{C}_{22} \mathrm{H}_{26} \mathrm{O}_{2} \mathrm{Na}$ : 345.1831.

5-(6-Hydroxy-6-methyl-5-oxoheptan-2-yl)-2-methylphenyl acetate (3a) The spectroscopic data of compound 3 a were reported previously [15].

5-(6-Hydroxy-6-methyl-5-oxoheptan-2-yl)-2-methylphenyl benzoate (3b) Compound $\mathbf{3 b}$ was obtained as a yellow oil in $43.78 \%$ yield: FTIR (KBr) $\mathrm{cm}^{-1}, 3492.04(\mathrm{O}-\mathrm{H}), 2969.65$ and 2929.93 (C-H aliphatic), 1736.23 ( $\mathrm{C}=\mathrm{O}$ ester), 1710.52 ( $\mathrm{C}=\mathrm{O}$ ketone), 1266.26 (C-0 ester), ${ }^{1} \mathrm{H}-\mathrm{NMR}(500$ $\left.\mathrm{MHz}, \mathrm{CDCl}_{3}\right), \delta(\mathrm{ppm}): 8.21(2 \mathrm{H}, \mathrm{d}, \mathrm{J}=6.55, \mathrm{Ar}-\mathrm{H}), 7.52(2 \mathrm{H}, \mathrm{m}, \mathrm{Ar}-\mathrm{H})$, $7.65(1 \mathrm{H}, \mathrm{m}, \mathrm{Ar}-\mathrm{H}), 7.2(1 \mathrm{H}, \mathrm{d}, \mathrm{J}=7.8, \mathrm{Ar}-\mathrm{H}), 7(1 \mathrm{H}, \mathrm{d}, \mathrm{J}=6,1, \mathrm{Ar}-\mathrm{H})$, $6.93(1 \mathrm{H}, \mathrm{s}, \mathrm{Ar}-\mathrm{H}), 3.74(1 \mathrm{H}, \mathrm{s},-\mathrm{OH}), 2.71(1 \mathrm{H}, \mathrm{m}, \mathrm{CH}-\mathrm{Ar}), 2.2\left(3 \mathrm{H}, \mathrm{s}, \mathrm{CH}_{3}-\right.$ $\mathrm{Ar}), 2.4\left(2 \mathrm{H}, \mathrm{m}, \mathrm{CH}_{2}-\mathrm{CH}_{2}-\mathrm{C}=0\right), 1.29\left(3 \mathrm{H}, \mathrm{s}, \mathrm{CH}_{3}-\mathrm{C}\right), 1.96$ and $1.87(2 \mathrm{H}, \mathrm{m}$, $\left.\mathrm{CH}-\mathrm{CH}_{2}-\mathrm{CH}_{2}\right), 1.29\left(3 \mathrm{H}, \mathrm{s}, \mathrm{CH}_{3}-\mathrm{C}\right), 1.28\left(3 \mathrm{H}, \mathrm{d}, \mathrm{J}=7,1, \mathrm{CH}_{3}-\mathrm{CH}\right),{ }^{13} \mathrm{C}-\mathrm{NMR}$ (500 MHz, $\mathrm{CDCl}_{3}$ ) $\delta$ (ppm): 214.69 (C=0 ketone), $165.09^{3}$ (C=0 benzoyl), 149.72 (C-0 benzoyl), 145.46 (CAr), 133.73 (CAr), 131.36 (CAr), 130.27 (CAr), 129.66 (CAr), 128.75 (CAr), 128.17 (CAr), 124.77 (CAr), 120.78 (CAr), $38.93(\mathrm{CH}-\mathrm{Ar}), 31.83\left(\mathrm{CH}-\mathrm{CH}_{2}-\mathrm{CH}_{2}\right), 33.62\left(\mathrm{CH}_{2}-\mathrm{CH}_{2}-\mathrm{C}=0\right), 26.57$ $\left(\mathrm{CH}_{3}-\mathrm{C}\right), 26.7\left(\mathrm{CH}_{3}-\mathrm{C}\right) 22.73\left(\mathrm{CH}_{3}-\mathrm{CH}\right), 16.03\left(\mathrm{CH}_{3}-\mathrm{Ar}\right), \mathrm{HR}$ ESI-MS m/z: 377.1718 [M+Na] $]^{+}$calculated for $\mathrm{C}_{22} \mathrm{H}_{26} \mathrm{O}_{4} \mathrm{Na}$ : 345.1729.

The FTIR spectra of $\mathbf{2 a}$ and $\mathbf{2} \mathbf{b}$ show bands corresponding to $\mathrm{C}=\mathrm{O}$ in ester groups at 1768.06 and $1737.9 \mathrm{~cm}^{-1}$, respectively. No bands of$\mathrm{OH}$ groups (expected at $3400 \mathrm{~cm}^{-1}$ ) are observed, indicating that the hydroxyl groups were all replaced by ester groups. This conclusion is supported by the ${ }^{12} \mathrm{C}$-NMR spectra, in which the signals of the carbon atoms in the ester groups are observed at 169.35 and $164.97 \mathrm{ppm}$ for $\mathbf{2 a}$ and $\mathbf{2 b}$, respectively.

The FTIR spectra of $\mathbf{3} \mathbf{a}$ and $\mathbf{3} \mathbf{b}$ show peaks corresponding to-OH groups at 3482.04 and $3492.04 \mathrm{~cm}^{-1}$, respectively. Ketone groups are also indicated by the peaks at 1709.98 and $1710.52 \mathrm{~cm}^{-1}$ in the spectra of $\mathbf{3} \mathbf{a}$ and $\mathbf{3} \mathbf{b}$, respectively. The previously formed ester groups (in $\mathbf{2 a}$ and $\mathbf{2 b}$ ) remained in $\mathbf{3} \mathbf{a}$ and $\mathbf{3} \mathbf{b}$. The FTIR results were supported by the ${ }^{13} \mathrm{C}$-NMR spectra of $\mathbf{3} \mathbf{a}$ and $\mathbf{3} \mathbf{b}$, in which the peaks corresponding to the carbon atoms of ketone groups are found at 214.5 and $214.69 \mathrm{ppm}$, respectively, and the peaks of the carbon atoms of- $\mathrm{OH}$ groups are located at 76.33 and $76.36 \mathrm{ppm}$, respectively. The ${ }^{1} \mathrm{H}-\mathrm{NMR}$ and HR-MS data also supported the reported structures of all compounds.

\section{Inhibition of NO production}

The inhibition of NO production by the synthesized products was evaluated in RAW 264.7 monocyte macrophage-like cells from BALB/c mice induced by Abelson leukemia virus. These cells have the ability to undergo pinocytosis and phagocytosis [20]. LPS, the main component of the bacterial cell wall, was used to stimulate NO production in the cells [21]. The NO inhibition assay indicated $\mathrm{IC}_{50}$ values for NO production of $73.85,354.05$, and $97.19 \mu \mathrm{M}$ for compounds $\mathbf{2 a}, \mathbf{3 a}$, and $\mathbf{3 b}$, respectively. In contrast, $\mathbf{2 b}$ did not inhibit NO production (Table 1). The $\mathrm{IC}_{50}$ values obtained for xanthorrhizol (1) and diclofenac sodium were 31.82 and $78.43 \mu \mathrm{M}$, respectively. Thus, $\mathbf{2 a}, \mathbf{3 a}$, and $\mathbf{3 b}$ had lower inhibitory activities for NO production compared to 1 .

Based on cytotoxicity assay, the $\mathrm{LD}_{50}$ values of compounds $\mathbf{2 a}, \mathbf{2} \mathbf{b}, \mathbf{3 a}$, and $\mathbf{3 b}$ were $65.15,31.15,117.86$, and $53.40 \mu \mathrm{M}$, respectively (Table 1 ). The $\mathrm{LD}_{50}$ values of compounds 1 and diclofenac sodium were 30.97 and $51.67 \mu \mathrm{M}$, respectively (Table 1). Thus, the cytotoxicities of the xanthorrhizol derivatives $\mathbf{2} \mathbf{a}, \mathbf{2} \mathbf{b}, \mathbf{3} \mathbf{a}$, and $\mathbf{3 b}$ were lower than that of 1 . These results indicate that all structural modifications of xanthorrhizol reduced the cytotoxicity. Xanthorrhizol has potential as an antiinflammatory agent, but it also was reported to have a high cytotoxic potential [7-10]. Further studies should be done to explore the relation of its pharmacological activity and cytotoxicity.

\section{CONCLUSION}

Ester derivatives of xanthorrhizol and its oxidation products were successfully synthesized. Compounds $\mathbf{2 a}$ and $\mathbf{2 b}$ were generated in yields of $58.49 \%$ and $63.26 \%$, respectively, through the esterification of the hydroxyl groups of xanthorrhizol. Compounds $\mathbf{3 a}$ and $\mathbf{3 b}$ were produced in yields of $51.92 \%$ and $43.78 \%$, respectively, by oxidizing $\mathbf{2 a}$ and $\mathbf{2 b}$ with $\mathrm{KMnO}_{4}$ to break the double bonds in the alkyl groups. The anti-inflammatory activities of the products were tested by NO inhibition assay using RAW 264.7 macrophage cells. The results indicated that the xanthorrhizol derivatives were less active against NO production compared to xanthorrhizol. However, cytotoxicity assay revealed that the modification of xanthorrhizol successfully reduced its toxicity.

\section{ACKNOWLEDGMENTS}

The authors are grateful to the Rector of Universitas Indonesia, Depok, Indonesia, for financially supporting this study (PITTA GRANT, 2018); to the Synthesis Laboratory, the Agency for the Assessment and Application of Technology (BPPT), Republic of Indonesia, for providing the facilities for this study; and to the Chemistry Study Program, Bandung Institute of Technology (ITB), Bandung, Indonesia, for recording NMR and HR-MS spectra.

\section{CONFLICTS OF INTEREST}

The authors declare that there are no conflicts of interest. 


\section{REFERENCES}

1. Rankin JA. Biological mediators of acute inflammation. AACN Clin Issues 2004;15:3-17.

2. Kam PC, See AU. Cyclo-oxygenase isoenzymes: Physiological and pharmacological role. Anaesthesia 2000;55:442-9.

3. Vishwanathan B, Gurupadayya BM, Sairam KV, Inturi BK. Design, synthesis, in vitro antioxidant and in vivo anti-inflammatory activities of novel oxadiazole derivatives. Int J Pharm Pharm Sci 2014;6:514-20.

4. Araujo LF, Soeiro Ade M, Fernandes Jde L, Serrano Júnior CV. Cardiovascular events: A class effect by COX-2 inhibitors. Arq Bras Cardiol 2005;85:222-9.

5. Ali SH, Kasim AA. The effect of prophylactic inhibition of inducible nitric oxide synthase by aminoguanidineon serum levels of some adipocytokines in pristane-induced arthritisin rats. Int J Pharm Pharm Sci 2015;7:178-83.

6. Bae SH, Ryu YS, Hong JH, Park JC, Kim YM, Seok JH, et al. Diclofenac inhibits IFN- $\gamma$ plus lipopolysaccharide-induced iNOS gene expression via suppression of NF- $\mathrm{kB}$ activation in RAW 264.7 macrophages. Korean J Physiol Pharm 2001;5:521-7.

7. Chung WY, Park JH, Kim MJ, Kim HO, Hwang JK, Lee SK, et al. Xanthorrhizol inhibits 12-O-tetradecanoylphorbol-13-acetate-induced acute inflammation and two-stage mouse skin carcinogenesis by blocking the expression of ornithine decarboxylase, cyclooxygenase- 2 and inducible nitric oxide synthase through mitogen-activated protein kinases and/or the nuclear factor-kappa B. Carcinogenesis 2007;28:1224-31.

8. Kang YJ, Park KK, Chung WY, Hwang JK, Lee SK. Xanthorrhizol, a natural sesquiterpenoid, induces apoptosis and growth arrest in HCT116 human colon cancer cells. J Pharmacol Sci 2009;111:276-84.

9. Kim MB, Kim C, Song Y, Hwang JK. Antihyperglycemic and antiinflammatory effects of standardized Curcuma xanthorrhiza Roxb. extract and its active compound xanthorrhizol in high-fat diet-induced obese mice. Evid Based Complement Alternat Med 2014;2014:205915.

10. Oon SF, Nallappan M, Tee TT, Shohaimi S, Kassim NK, Sa'ariwijaya MS, et al. Xanthorrhizol: A review of its pharmacological activities and anticancer properties. Cancer Cell Int 2015;15:100.

11. Park JH, Jung YJ, Shrestha S, Lee SM, Lee TH, Lee CH, et al. Inhibition of NO production in LPS-stimulated RAW 264.7 macrophage cells with curcuminoids and xanthorrhizol from the rhizome of Curcuma xanthorrhiza Roxb. and quantitative analysis using HPLC. J Korean Soc Appl Biol Chem 2014;57:407-12.

12. Aguilar MI, Delgado G, Villarreal ML. New bioactive derivatives of xanthorrhizol. Rev Soc Quím Mex 2001;45:56-9.

13. Sirat HM, Hong NM, Jauri MH. Chemistry of xanthorrhizol: Synthesis of several bisabolane sesquiterpenoids from xanthorrhizol. Tetrahedron Lett 2007;48:457-60

14. Das S, Patel S, Mishra BK. Oxidation by permanganate: Synthetic and mechanistic aspects. Tetrahedron 2009;65:707-39.

15. Rahayu M, Kusumaningrum S, Hayun H. 5-(6-Hydroxy-6-methyl-5oxoheptan-2-yl)-2-methyl phenyl acetate. Molbank 2019;2019:M1041.

16. Lugemwa FN, Shaikh K, Hochstedt E. Facile and efficient acetylation of primary alcohols and phenols with acetic anhydride catalyzed by dried sodium bicarbonate. Catalysts 2013;3:954-65

17. de Morais SM, Vila-Nova NS, Bevilaqua CM, Rondon FC, Lobo CH, de Alencar Araripe Noronha Moura A, et al. Thymol and eugenol derivatives as potential antileishmanial agents. Bioorg Med Chem 2014;22:6250-5.

18. Alimuddin AH, Mardjan MI, Matsjeh S, Anwar C, Mustofa M, Sholikhah EN. Synthesis 7-hydroxy-3', 4'-dimethoxyisoflavon from eugenol. Indones J Chem 2011;11:163-8.

19. Cheenpracha S, Park EJ, Rostama B, Pezzuto JM, Chang LC. Inhibition of nitric oxide (NO) production in lipopolysaccharide (LPS)-activated murine macrophage RAW 264.7 cells by the norsesterterpene peroxide, epimuqubilin A. Mar Drugs 2010;8:429-37.

20. Taciak B, Białasek M, Braniewska A, Sas Z, Sawicka P, Kiraga $Ł$, et al. Evaluation of phenotypic and functional stability of RAW 264.7 cell line through serial passages. PLoS One 2018;13:e0198943.

21. Ngkelo A, Meja K, Yeadon M, Adcock I, Kirkham PA. LPS induced inflammatory responses in human peripheral blood mononuclear cells is mediated through NOX4 and Gi $\alpha$ dependent PI-3kinase signalling. J Inflam 2012;9:1-7. 